\title{
El mundo nuevo en la mente ibérica y sajona*
}

Juan A. Ortega y Medina

\begin{abstract}
$\mathrm{E}$ ncontrándose Don Quijote rodeado de rústicos y atónitos cabreros en Sierra Morena, el caballero, sosteniendo en una de sus manos un puñado de bellotas, les espetó el famoso y evocador discurso sobre la, ay, ya ida y siempre añorada edad de oro.

Dichosa edad y siglos dichosos - comenzó el Caballero de la Triste Figura- a quien los antiguos le pusieron el nombre de dorados, y no porque en ellos el oro, que en esta nuestra edad de hierro tanto se estima, se alcanzase en aquella venturosa sin fatiga alguna, sino porque entonces los que en ella vivían ignoraban estas dos palabras "tuyo" y "mío". Eran en aquella santa edad todas las cosas comunes; a nadie le era necesario para alcanzar su ordinario sustento tomar otro trabajo que alzar la mano y alcanzarle de las robustas encinas, que libremente les estaban convidando con su dulce sazonado fruto... Todo era paz entonces, todo amistad, todo concordia.
\end{abstract}

Cervantes, en aquella edad férrea y conflictiva en que las potencias europeas guerreaban incansablemente disputándose hegemonías, recuerda la tradición clásica iniciada por Hesiodo, el pastor beocio en Los trabajos y los dias, que culmina en el mundo latino con Virgilio y que sobre todo a partir del poeta, se presenta bifurcada interpretativamente en la versión progresista optimista de Lucrecio Caro, De la naturaleza de las cosas, y en la exégesis del filósofo pedagogo latinocordobés Lucio Anneo Séneca, quien en su desesperanzada Epístola $\mathrm{XC}$ alude evocadoramente a las tres edades del mundo (oro, plata, bronce-hierro) caracterizada la última, que era la suya, por la violencia y la degeneración física y moral (s.I.d.C.); por los vicios, las guerras y el licantropismo político.

Los poetas buscan la manera de escapar, al menos bucólicamente, de tan triste cuanto miserable etapa férrea e imaginan a manera de compensación ilusoria utópica una Arcadia habitada por pastores (arcadios o árcades) donde reina la abundancia, la inocencia y la felicidad.

Durante los siglos medievales cristianos, centurias violentas guerreras, codiciosas y hasta despiadadas de vez en cuando, paulatinamente se van dulcificando por la caridad cristiana; por la dignificación del amor y el culto galante a la mujer; por la belleza del románico y del ojival; por la claridad de las Summa theologica del aquinense y por las cortes de amor borgoñonas que van puliendo y refinando toscos modos y costumbres. A lo largo de esta Edad Media no tan sombría, sin embargo, como el Renacimiento la consideró, la edad áurea de la literatura pagana se convierte en el Edén o Paraíso perdido que hay que encontrar, como creyó haberlo localizado Crístóbal Colón aguas arriba del caudaloso río Orinoco.

* Conferencia sustentada en la Facultad de Filosofía y Letras en el ciclo "500 años de historia: sentido y proyección", organizado por la Comisión Nacional Conmemorativa del V Centenario, del 28 de junio al 21 de julio de 1988. 
Humanistas y artistas del Renacimiento redescubren a su vez el tema clásico de la Edad de Oro y del ente dichoso que vivía y gozaba de ella. Pero esta vez la utopía se topiza o, por mejor decirlo, se terrenaliza, como escribió Eugenio Ímaz. La presencia real de América, previa su invención por los poetas y humanistas, como expresara con certeza Alfonso Reyes en La última Thule, transforma la primigenia. utopía en sueño despierto o ensoñación de casi Paraíso terrenal habitada por seres humanos bondadosos y nobles, que conviven armoniosa y felizmente en una tierra fragante, rica y bella que les cede sus más opimos frutos sin mayores esfuerzos. La supuesta áurea edad se convierte en realidad americana, no menos que el famoso filósofo desnudo de los antiguos se concreta y actualiza en el hermoso, débil, mansuetísimo, discurrente y racional salvaje isleño. La escena, reconstruida al estilo clásico, corre a cuenta de Pedro Mártir de Anglería: un anciano y grave indio todo desnudo se acerca al Almirante por antonomasia, a Cristóbal Colón, por supuesto, y tras obsequiarle un canastillo lleno de flores y frutos le dirige este discurso:

Nos han contado que tú has recorrido con ejércitos poderosos todas estas provincias que hasta ahora te eran desconocidas, y que has causado no poco miedo a los pueblos que las habitan. Por lo cual te advierto y amonesto que las almas, cuando salen del cuerpo, tienen dos caminos: uno tenebroso y horrible, preparado para aquellos que hacen daño al género humano; otro placentero y deleitable, destinado para los que en vida amaron la paz y tranquilidad de las gentes. Si, pues, tienes presente que eres mortal, y que a cada uno le están señalados los méritos futuros según las obras presentes, no harás mal a nadie.

Colón quedó naturalmente maravillado con aquel breve y sentencioso discurso proveniente de "un hombre desnudo", máximo cargo que según Montaigne hacían los civilizados europeos a los indios por no llevar calzones. Hay que imaginar que el octogenario indígena quedó asimismo pasmado con la réplica de Colón, especialmente cuando éste explicó su presencia en aquel mundo natural virgen para castigar por orden de los reyes de España, según dijo, a los caníbales y a otros malos hombres, y para honrar y defender a los buenos.

Colón busca riquezas y como aquellos primitivos isleños no daban muestra de poseer muchas, entonces se siente obligado a disimular su desencanto áureo, a distraer la atención de sus receptores epistolares, mediante la descripción de las edénicas islas que iba descubriendo ("muy bellas, de montes sublimes y agradables vistas, de campos feraces") y de los habitantes ("gentes ingeniosas, bien proporcionadas, como calcas de antiguas estampas, tímidas y espléndidas, inocentes, de bonísima fe y dadivosas"). Tal descripción no pudo menos que mover la pluma del cronista ya citado, Pedro Mártir, y le hizo escribir:

Tienen ellos por cierto que la tierra así como el sol y el agua es común y que no debe haber entre ellos mío y iuyo, semillas de todos los males, pues se contentan con tan poco, que en aquel vasto territorio más sobran campos que no le falta a nadie nada. Para ellos es la edad de oro [subrayado nuestro]. No cierran sus heredades ni con fosos, ni con paredes ni con setos; viven en huertos abiertos, sin leyes, sin libros, sin jueces; de su natural veneran al que es recto; tienen por malos y perversos al que se complace en hacer injuria a cualquiera; sin embargo, cultivan el maiz, la yuca y los ajíes. 
El segundo gran navegante, Américo Vespucio, confirmaria también que la gente vista por él en la cuarta parte del mundo vivía y se contentaba con lo que buenamente le daba la naturaleza; que tenía en poco la riqueza y que, por lo mismo, resultaba extremadamente liberal. Empero al lado de esta descripción amable y eldorádica, en la carta conocida por lo general como Cuatro viajes aparece ya la otra cara, la del indio indómito y fiero, guerrero y caníbal, cruel y traicionero; bestial, en suma. Asimismo, Colón, desde su primera carta, se refiere a otros indios "muy feroces", nada amables; de largos cabellos, los cuales en la carta del doctor Chanca al cabildo de la ciudad de Sevilla, escrita probablemente a fines de enero de 1494, después de la primera expedición de Ojeda, dando cuenta del segundo viaje del Almirante, son habitantes de las islas Caribes y "come carne cruda o viva", expresión que traducida al latín por Cozco se transformó en "hi carne humana vescuntur", es decir, estos se alimentan de carne humana. Colón mencionaba a los indios de las islas Caribs simplemente de oídas, y por esta vía explicatoria, epistolar y semántica, los caribs o caribes, que según parece no eran antropófagos, quedaron calificados como caníbales.

Sea como fuere, los testimonios españoles y portugueses, así como de sus traductores y navegantes italianos, confirman -y no importa para nuestro objeto que dichos testimonios sean falsos o verdaderosla presencia de la otra faz negativa del indio americano. Al repararse por primera vez la presencia en el género humano de un ente nuevo, de una cuarta raza, la americana roja, que ponía en crisis la tradicional división jerárquica del ecumene y de sus habitantes, la cara del indio aparece como la del noble y buen salvaje, que casi de inmediato se trueca en su contraria, la del mal salvaje, no ya tan sólo bárbaro, mal menor, sino de naturaleza bestial. El relevado positivo tenía el respaldo de la fábula clásica y de la renovación renacentista; el negativo se apoyaba en la conceptuación inventada, manipulada o asumida por los historiadores y cronistas. Como escribió con irónica precisión Alfonso Reyes, el "filósofo desnudo" de Pedro Mártir de Anglería, personaje central en el drama histórico, "prepara [ba] ya el buen salvaje de Rousseau, y el fastuoso exotismo del mundo antiguo y del medieval se transforma en el exotismo americano".

Con ayuda del padre Las Casas y de otros ardientes críticos españoles, llegaron otros no tan puramente desinteresados y provistos con grandes dosis de hipocresía a lamentar la efimera vida de la etapa áurea americana y de su ente más representativo, el noble y buen salvaje. La protesta enconada y justiciera, según es sabido, partió ante todo de la propia España e inmediatamente cundió la condena en todas las naciones europeas enemigas del imperio español del siglo $\mathrm{XVI}$, no tanto por motivos humanitarios sino por principios religiosopolíticos y por contrapuestos intereses económicos. El monumento jurídico más excelso del iusnaturalismo español de la centuria decimosexta (La brevísima, 1552) se convirtió en plumas ajenas enemigas en un instrumento propagandista formidable para condenar a los aborrecidos españoles y fundamentar la llamada leyenda negra, todavía vigente.

Países como Inglaterrra, Holanda, Francia y Suecia tuvieron también que concertar y contender con el indio americano y de hecho lo hicieron no con el ente mítico ideal, el noble salvaje imaginado durante los primeros contactos de los navegantes europeos, sino con un ser 
real, astuto, hostil o cordial según las circunstancias. Sin embargo el poder embelesador de la leyenda áurea y del indio paradisiaco estaba de cierto modo tan arraigado que nunca se extinguió del todo, tal como lo prueba su renacer en el Siglo de las Luces.

En el siglo xvi, movidos los ingleses de la época isabelina por la sugestiva y nostálgica ilusión de la edad dorada, al ponerse en contacto con el piel roja no pudieron menos de idealizar en su turno y como era de rigor la presencia física y moral de éste. El capitán Barlow, enviado por Walter Raleigh a colonizar la tierra americana, que sería llamada Virginia en honor de la reina, describe a los hombres y mujeres de la tribu como gente hermosa, bondadosa y civilizada:

Cuando nos acercamos [en nuestro batel] y allegamos cabe a la orilla del mar, la esposa de Granganimeo vino corriendo a saludarnos muy afectuosa y amigablemente. Su marido no estaba en ese momento en la aldea, y ella mandó entonces a algunos de los suyos que nos remolcasen hasta la orilla donde rompían las olas; encargó a otros que nos llevasen a cuestas hasta la playa, y a otros que recogiesen nuestros remos y los llevasen a la casa, no fueran a robárnoslos. Cuando entramos en el aposento exterior (porque la vivienda tenía cinco) nos hizo sentar en torno a un gran fuego y después de quitarnos la ropa y tras lavarla y secarla, algunas de las doncellas presentes nos quitaron las medias y las lavaron y otras lavaron también nuestros pies con agua caliente. La cacica se esforzó cuanto pudo en atendernos y en ordenar las cosas de la mejor manera que pudo dándose mucha prisa en prepararnos algo de comer. Después de habernos secado nos pasó a una habitación interior y puso sobre la mesa, que corria a lo largo de la casa, cierto manjar que parecía hecho de trigo, además de carne de venado curada y asada, pescado seco, cocido y asado, melones en crudo y preparados, raíces de diversas especies y frutos variados. La bebida de los indios es por lo general agua; pero preparada con jengibre y canela negra, $\mathrm{y}$ a veces sasafrás $\mathrm{y}$ otras hierbas $\mathrm{y}$ hojas salutíferas $\mathrm{y}$ medicinales. Nos atendieron, pues, con todo amor y fineza y con la mayor liberalidad que, a su manera, les fue posible. Hallamos a aquella gente muy mansa, amorosa, fiel y sin malicia, y tal como si estuvieran viviendo aún en la edad dorada [cursivas nuestras].

Por lo que se refiere a la tierra, al acercarse el capitán Barlow en su nave a la sonda de Pamlico (1584) percibió aromas y fragancias deleitosas: "el día 2 de julio -escribe en su informe- hallamos aguas poco profundas y percibimos un tan dulce y penetrante olor que parecía como si estuviéramos en medio de un delicado vergel cuajado de toda suerte de odoriferas flores".

$Y$ cuando el hermano del "rey" Granganimeo llegó en una de las canoas indias a saludar a los ingleses, Barlow escribe: "arribó acompañado de cincuenta guerreros, gente hermosa y bondadosa que mostró asi en su conducta como en sus modales, tanta civilidad como la que hubiera podido mostrar cualquier nación de Europa". Por el momento la naturaleza y el hombre americanos se mostraban idealmente potenciados, realzados, que era como tenía que ser o, mucho mejor, como se quería comprobar que fuesen en este primer abordaje edénico, con los ojos muy abiertos, ávidos y asombrados de estos primeros navegantes nórdicos europeos. Como en el caso de Colón, a falta de oro y especias había que dirigir la atención del ansioso y maravillado lector -en este caso el empresario y fautor de la colonización anglosajona en América, Sir Walter Raleigh- hacia la bondad 
del clima, el verdor de los árboles y follaje, los trinos de las aves y la inocencia de los naturales. La magnífica presencia física de estos in puribus, permitió que la lente estilística mediterránea y nórdica - grabados respectivamente de fray Diego Valadés y de Teodoro de Bry, por ejemplo- captase esta notable realidad que desbordaba los raquíticos módulos fisiológicos de la mayoría de los habitantes del Viejo Mundo, tal y como lo comprobaría y testimoniaría Raleigh al ponerse en contacto con los indios caribes de la Guayana, los indios mejor dotados y más musculosos que asombrarían asimismo a Humboldt a comienzos del siglo XIX.

Fue el doctor José Gaos quien al estudiar la obra de fray Antonio de Guevara, Reloj de príncipes o Marco Aurelio, puso atención en una novelita didáctica, a la moda de entonces, El villano del Danubio, incluida en el texto, que es "una expresión más de la autocrítica de la España conquistadora de América, iniciada y llevada adelante con creciente volumen y eficacia por los evangelizadores". En efecto, las quejas del villano en la corte imperial y en presencia del emperador Marco Aurelio se refieren a los agravios y entuertos que reciben los pobres riparios danubienses por mano y obra de un ambicioso y desaforado censor romano. El discurso del villano es largo y por ello no lo incluimos en esta exposición; pero al lector que se sienta inclinado a conocer las denuncias del germano ante la opresión de la Roma conquistadora, le aconsejamos que donde lea "villano" o "rústico" imagine indio o buen salvaje; donde lea "Marco Aurelio" piense en Carlos V; tome por Cortes españolas el "Senado"; y en lugar de "Roma" o "Italia" traduzca España; en vez de "Germania", las Indias y tenga a los "romanos" por castellanos y a los "capitanes de Roma" por capitanes conquistadores. Y por último, considere a los "padres conscriptos" o "senadores" por procuradores castellanos. Con el simple trastrueque de los sujetos el lector puede penetrar simbólica y críticamente en la intencionada y santa ficción del fraile, que criticando la conquista romana de hacía quince siglos censuraba la espanola que se estaba llevando a cabo con violencia e injusticias en las Indias.

Lo que a un alto nivel crítico realizó fray Antonio de Guevara con su novelada interpolación, lo van a llevar a cabo en un nivel popular Micael de Carvajal y Luis Hurtado de Mendoza en la mascarada espiritual Las cortes de la muerte (inspirada en las danzas medievales de la muerte). Como ocurre en este tipo de farsa teatral, todos los personajes y estamentos sociales van desfilando ante la Muerte, arbitrando cada quien sus muy vitales razones para que su vivir se alargue; pero la Descarnada no hace caso a sus alegatos y va remitiéndolos uno por uno al "escuro", sin que valgan lloros, lamentos o súplicas. En la escena xIx del auto hace acto de presencia la novedad americana, la incorporación de lo original primigenio, la queja indigna, con aires de utopia condolida: la presentación del sufrido y buen salvaje en el escenario histórico teatral.

Caciques e indios aprovechan su obligado desfile en las Cortes de la Muerte para exponer de viva voz todas las injusticias que se cometen con ellos, todos los daños y abusos de que son objeto por parte de sus encomenderos. Lo curioso, además de inteligentísimo, es que los autores van a utilizar los mismos terribles alegatos que el padre Las Casas empleó con energuménica, exagerada y santa furia cristiana en La brevisima, poniéndolos en boca de los dolientes indígenas. 
Por supuesto los españoles son condenados con la consagrada expresión virgiliana, auri sacra fames de los conquistadores, y sus desmanes, atropellos y asesinatos de gente inocente son crudamente exhibidos: "Por robar hacienda y fama -expresa uno de los caciques querellantes- / ¿Qué hija. mujer ni hermana / Tenemos que no haya sido / Más que pública, mundana / Por esta gente tirana/Que todo lo ha corrompido?/Para sacar los anillos/ ¿Qué dedos no se cortaron?/ ¿Qué orejas para zarcillos / No rompieron con cuchillos ? ¿Qué brazos no destrozaron? / ¿Qué vientre no traspasaron / Las espadas con gran lloro...?

Si uno recuerda que por el páramo manchego se topó Don Quijote con la carreta de la compañía de Angulo el Malo, que iba representado por aquellos pueblos de Dios del Auto de las Cortes de la Muerte, y que el héroe hizo correr lanza en ristre a los despavoridos y pobres cómicos de la legua, se cae en la cuenta de la presencia del indio y de las Indias en la conciencia popular española. Por lo tanto, resulta sumamente ilustrativo y emocionante comprobar cómo el tema crucial americano, el noble y cuitado indio, fue motivo de reflexión, compasión y disputa no sólo en los círculos españoles cultivados, sino también en la conciencia lugareña zafia y ruda: la de los rústicos españoles de los siglos XVI y XVII. Opinión popular forjada en relación con el cándido y desgraciado indio; el hombre natural provisto de razones persuasivas y justas; el hombre exento de codicia y de sed de oro (versos 86-100); extraño a las crudas guerras (v. 35); inerme y dichoso (vv. 251-260); incapaz de hacer daño (v. 262); inofensivo, "triste mora a quienes todos tocan" (vv. 269-270).

Como puede considerarse, la autocrítica española no se había detenido en las cabezas humanistas y en las de los teólogos, sino que había desbordado y llevado su flamígera verdad al corazón del pueblo. Autocrítica original, feroz y despiadada como ninguna otra nación antes o después se ha dado el contrito y mortificante lujo de realizar. El vulgo español lograba así una visión positiva: la del noble indio, el indio sosegado y bueno; el hombre en estado de naturaleza, pero no bruto y sin razón, asimilable a la animalidad, sino un ente racional dotado plenamente de humanidad cristiana, compadecido y redimido, en tanto que hombre, por la sangre de Cristo. De no ser así no podría explicarse la présencia del indio en las cortes junto con los demás convocados.

Como lo hemos hecho, tócanos apreciar ahora, tras las versiones críticas españolas acerca de las imágenes literarias recreadas sobre el buen salvaje y los efectos de su inclusión y sometimiento en el mundo hispánico, la incorporación del indio en el marco de la extraordinaria dramaturgia shakespeariana. Como es sabido, la preocupación de Shakespeare por América surgió tras el naúfragio en las Bermudas (1609) de la nao capitana de una flota ingiesa al mando del almirante Sir Thomas Gate y, sobre todo, por la lectura crítica de Montaigne, quien a su vez se sintió inspiradamente horrorizado por las crónicas e historias españolas sobre el Nuevo Mundo y sus desgraciados habitantes. El pensador argentino Aníbal Ponce, fallecido accidentalmente en México en 1938, escribió un interesante libro titulado Humanismo burgués y humanismo proletario (1938), en donde realiza un ingenioso estudio sobre La tempestad, obra del dramaturgo inglés en la que éste justifica el incipiente imperialismo británico del siglo XVI. El descubrimiento de islas perdidas en la inmensidad del océano, adonde arri- 
ban náufragos para reconstruir utopias, lejos de la influencia degradante de la férrea edad tercera en que vive sumergido el Viejo Mundo, constituye el tema clásico y dramático de la época; válvula crítica de escape, por un lado, y, por el otro, incitación promocional para las nuevas aventuras descubridoras, conquistadoras y colonizadoras allende el océano.

Próspero, usurpador de una de las tales islas, es en la interpretación de Aníbal Ponce el típico tirano renacentista que con sus artes mágicas ha vencido a la bruja, la dueña legítima de la ínsula, y ha esclavizado al heredero de ésta, el monstruoso Calibán, al cual pone a su servicio. El usurpador libera también al genio Ariel, prisionero de la bruja, al que a veces alaba ("gentil y bravo espíritu"), pero al que asimismo castiga e insulta cuando demanda su libertad (mentiroso, "maldito ser"). En suma, Próspero, humanista y mago, hombre al que Shakespeare presenta como indulgente, amante del bien y proclive al perdón, así como su hija Miranda, se sirven por igual del teratológico pero útil Calibán y del alado espíritu cuyo reino es el aire. Ambos seres, el espiritual y el material, aspiran a la libertad; pero las artes del mago los tiene aherrojados y son inútiles los insultos y cóleras del uno así como las súplicas y cortesías del otro frente al autócrata.

Nuevos náufragos llegan a la misteriosa isla y Calibán aprovecha la ocasión para conspirar con ellos contra el tirano; pero advertido Próspero, que cuenta con los servicios de Ariel, con gran facilidad y despertando la codicia de los conspiradores derrota a los intrusos. Calibán, vencido y humillado, reconoce su falta y acepta sumiso su destino de obediente pobre diablo, sólo útil cuando está al servicio de su amo; Ariel, por contra, obtiene de Próspero la libertad y emprende el vuelo para perderse feliz entre las nubes y reintegrarse a su etéreo elemento: el aire puro y azul.

En 1878 la leyenda de Ariel es motivo de la preocupación del gran humanista francés Ernest Renan, poseedor de la sabiduría de Erasmo y de la ironía de Montaigne. Aníbal Ponce hace reflexionar al lector sobre el hecho de que cuando el intelectual galo escribe, como éste dice, "su nueva confesión espiritual" o Calibán, continuación de la tempestad, drama filosófico, ya han pasado sobre él dos revoluciones (1848 y 1879). Calibán, prosigue el escritor argentino, "el odioso monstruo rojo" de Renan y de Shakespeare, vuelve a conspirar contra Próspero; mas esta vez triunfa el rebelde porque su incredulidad lo hace inmune a los hechizos y artes mágicas de su amo, y por la ayuda que le presta Ariel. Próspero abdica a favor de Calibán, éste se pronuncia contra los libros y el latín, instrumentos del poder intelectual mediante los cuales se domina al pueblo. Ariel, ofendido por no poder influir en el nuevo e impuro dictador, decide morir; los antiguos cortesanos rodean ahora al nuevo amo, lo adulan, reblandecen y quiebran la obstinada intransigencia del monstruo, hasta el punto de que éste otorga al vencido Próspero una beca de estudio. Y para que nada falte, un legado papal bendice a Calibán y reconoce diplomáticamente el nuevo orden político.

El pensador Aníbal Ponce, de filiación marxista, es el primer latinoamericano que reinterpreta la fantasía shakesperiana como fiel reflejo de la sociedad burguesa renacentista y protestante, y no, según se había creído, como mera apariencia de valores estéticos. Próspero representa, pues, simbólicamente al "déspota [americano] que no 
tolera otra voluntad que la suya" y tiene a su servicio a Calibán, al que explota inmisericordemente, al que desprecia ("infecto esclavo", "pedazo de estiércol"), pero al que necesita para poder sostener la civilización elitista fundada por el culto tirano de la isla. Ariel representa la inteligencia egoísta (homo pro se), ajena o desdeñosa del mundo real de los hombres comunes; pero Ariel, remata Anibal Ponce, "no gozaría en el aire su libertad de espíritu si Calibán no llevara leña hasta la estufa junto a la cual Próspero relee sus viejos libros".

Otro escritor hispanoamericano, Roberto Fernández Retamar, marxista cubano, propiciará un singular vuelco interpretativo a la figura de Calibán; a saber, dará un paso más adelante en su Calibán. Apuntes sobre la cultura en nuestra América (1971), y partiendo del anagrama shakespeariano (canibal: Calibán) nos hace ver que si bien el dramaturgo inglés se inspiró en el ensayo de Montaigne, De los caníbales, no consideró como el ensayista francés que tales supuestos salvajes nada tenían de bárbaros. Según Fernández Retamar el monstruo creado por Shakespeare, Calibán, es el hombre concreto americano, el esclavo salvaje al que no sólo es factible sino legítimo robarle la tierra, explotarlo, vivir de su trabajo e inclusive exterminarlo. La tempestad alude, sin duda, a América, afirma el autor, y el ambiente americano de la isla misteriosa, prosigue citando a Astrana Marín, el traductor de Shakespeare, es claramente indiano. Situado así en esta pendiente interpretativa, Fernández Retamar escribe "que Calibán es nuestro [indio] caribe, el mismo cuya doble falsa imagen forjara Colón a partir del primer contacto, ya, por lo tanto, en su versión del buen salvaje (el taíno o araguaco de la isla de Cuba) o del mal salvaje (el caribe o caníbal), cuya mansedumbre o bestialidad los hace respectivamente candidatos ideales para la extinción en tanto que víctimas del instinto homicida del colonizador".

La diferencia más marcada entre la colonización ibérica y la anglosajona en América se encuentra en el hecho de que tras la irrupción violenta guerrera, debeladora, y sometidos los indios, en el caso primero éstos pasaron a formar parte del imperio hispánico y durante trescientos años contribuyeron económica, política, cultural y biológicamente al surgimiento en la centuria decimonónica de las naciones latinoamericanas. El indio de las colonias españolas, el indio agricultor, minero o artesano fue, por supuesto, explotado en cuanto fuerza de trabajo; pero en calidad de súbdito directo de la Corona e hijo espiritual de la iglesia católica fue considerado como parte integral del imperio mediante el status legalista que unificaba las partes centrífugas (hombre y tierra) del mismo. En cuanto a los estratos jerárquicos de la nobleza indígena, fueron asimilados y nivelados a la misma altura de la aristocracia española de la que pasaron a formar parte. No podemos decir lo mismo de la situación del indio en las colonias inglesas de América, pues nunca formaron parte del status imperial británico y como marginados del mismo sólo estuvo expedito para ellos el "sendero de lágrimas" que conducía a la implacable destrucción. En la política colonial britániea, y en la norteamericana; el indio no tuvo ningún lugar específico; en cierto sentido podemos decir que el piel roja no existió como persona. Consideraciones teológicas puritanas, es decir calvinistas, contribuyeron al rechazo mucho más que el grado económico social alcanzado por las tribus pieles rojas, supuesto que las órdenes religiosas españolas y francesas lograron éxitos sorprendentes con los indigenas, cuyo nivel civilizador era análogo al de 
aquellas: Canadá, California, noroeste de México, Paraguay, etcétera.

Guerras destructoras contra los indios fueron la tónica general en las colonias inglesas, seguidas de paces precarias que volvían a quebrarse ante la incesante teluris sacra fames de los colonos, digamos para equilibrar el hambre sacra de oro con que quedaron caracterizados los ambiciosos conquistadores españoles del siglo XVI. Heredaron los norteamericanos esta telúrica sed y aplicaron a los poseedores originales de la tierra americana la misma ley de hierro que los ingleses habían aplicado a los "bárbaros" católicos irlandeses de los siglos XIV, xv y XVI: "el mejor irlandés -expresaban los conquistadores- es el irlandés muerto", que viene a ser lo mismo en cuanto a acción destructiva a lo que el general nortéamericano Sheridan replicó al cacique comanche Tochowag (Tórtola) que se presentó como "indio bueno": "que el mejor indio era el indio muerto".

En el último tercio del siglo XIX, una sensible autora norteamericana, Helen Hunt Jackson, escribió un pequeño y acusador libro al que tituló $A$ Century of Dishonor, indignada denuncia de un siglo norteamericano caracterizado por las más horripilantes destrucciones de indios. Se trata de la exposición rigurosamente verificada, con apoyos documentales auténticos, de la más prodigiosa empresa colonial de todos los tiempos: la colosal masacre o, mejor digamos en español, carnicería o genocidio de pieles rojas.

Recuerda la escritora estadunidense que bajo la presidencia de Jorge Washington una circular del Congreso de los Estados Unidos proclamó "que los pieles rojas estaban privados por naturaleza de la dignidad moral que distingue al hombre de la bestia" y que por lo mismo "debían ser aniquilados totalmente". A consecuencia de esta circular, prosigue la autora, cientos de miles de iroqueses, cheroquíes y mohicanos fueron exterminados de 1775 a 1798 .

Fue otro presidente de los Estados Unidos, Andrew Jackson, prosigue implacable la historiadora, quien declaró que "el piel roja es un animal pernicioso" y llevó a cabo la limpieza de tales bestezuelas asesinando en 1819 a más de 40000 . La destrucción sistemática de las tribus fue organizada de 1830 a 1890 por los sucesivos gobiernos de la Unión Americana.

Una de las matanzas que nos recuerda Helen Hunt Jackson fue la realizada por el coronel y ministro del Señor, el reverendo Chelington, de los fusileros del Colorado (1863). Los indios se habían rendido a discreción, cuando irrumpieron los soldados gubernamentales matando a tiros y bayonetazos a los hombres primeramente, después a las mujeres y por último a los niños, estrellando las cabezas infantıles contra las rocas. Los archivos americanos se resisten todavía, nos dice la investigadora, a proporcionar informes testimoniales sobre una encuesta nacional a gran escala acerca de aquella demoniaca acción militar en la que perecieron millares de mujeres y niños indígenas.

La Secretaría de Guerra, escribe la denunciante, ha prohibido la publicación detallada de tales hechos, y de la misma manera se ha opuesto a la publicación de la vida del jefe de los apaches, Gerónimo. Se trata de un documento revelador en el que se muestra cómo los oficiales americanos añadian metódicamente estricnina al aguardiente paia hacer desaparecer más rápidamente las aldeas indigenas. Los apaches, que eran unos 100000 al comienzo del siglo XIX, se habían reducido hacia 1880 a unos 20000 y para 1897 sólo quedaban unos centenares. 
No vale la pena proseguir con tan desdichados ejemplos y con la muestra que hemos extractado basta para hacerse cargo del gran drama de los indios estadunidenses. Existe en nuestro tiempo una nueva y doliente versión norteamericana que viene a ser, permíiaseme decirlo así, una desgarradora visión de los vencidos pieles rojas, escrita también por un norteamericano, Dee Brown, en donde el novelista e historiador hace justicia a los héroes indios exterminados: "Enterrad mi corazón en Wounded Knee".

Empero, pese a lo dicho, no conviene que nos enorgullezcamos ni nos demos tampoco baños de pureza por lo que toca a las relaciones del México independiente con nuestros indios. La llamada "guerra de castas" en Yucatán no representa ningún título de honor para nuestra antigua política indigenista, ni lo es para la época juarista, en la que las sublevaciones de indios en diversas partes del territorio nacional, y particularmente en Chiapas (cuatro en 1869), según relata el historiador Vicente Pineda, fueron aplastadas sin misericordia. Tampoco el régimen porfirista se libra del estigma, pues tan cerca de la capital como Chalco o tan lejos como Quintana Roo (1903) los generales Aureliano Blanquet y Victoriano Huerta combatieron con inaudita ferocidad a los acorralados indios mayas. Nuestra guerrita colonial interna, la guerra del yaqui, se libró durante años por la simplísima razón de que los indios sonorenses querían conservar sus tierras de labor ambicionadas por los yoris insaciables: los criollos blancos.

No queremos terminar este trabajo sin retrotraernos en el recuerdo a los primeros contactos de los europeos con el mundo americano. Tócale pues el turno final a una poetisa, Josephine Miles, que emocionada por la lectura de otro libro reivindicador del mundo indígena: Los salvajes de América. Un estudio sobre los indios y sobre la idea de civilización, de Roy Harvey Pearce, ha escrito un irónico y simbólico poema, Los salvajes, que me he permitido traducir, arriesgándome incluso a incurrir en la falla denunciada por el conocido aforismo italiano: traduttore, traditore.

Los SALVAJes

Bogábamos y nos alejábamos de nuestras naos, y al poner los pies sobre la playa,

en las tranquilas ensenadas, encontramos nuestras imágenes.

Nuestras bronceadas imágenes emergieron de los espejos del bosque como sombras ululantes y así escudriñamos nuestras almas.

$Y$ en ese infierno y gozo del paraíso hombre fijamos el lugar de sus formas rojizas, debemos ser crueles con nosotros mismos.

Más tarde, atravesando la maleza se arruinaron nuestras esperanzas al adentrarnos bosque tras bosque por donde del íntimo silencio el Misisipi fluye.

Y nos emboscaron cabe a la mera fuente, escalpados hasta la corteza. Aun asi los compramos.

Fue un acto amoroso para intentar salvarlos. 
El presidente Jackson preguntó:

¿Qué buen ciudadano antepondría un país boscoso poblado de salvajes

a nuestra república tachonada de ciudades, con todo el perfeccionamiento que el arte puede inventar o la industria producir?

El pastor Smiley inquirió:

¿Qué buen hombre permitiría que sus pecados o los de sus vecinos se vistiesen de hombres y corriesen por los montes para aparecer de pronto en ocasiones inocentes?

La señorita Benedict propuso:

La parcial era de la ilustración en que vivimos atrae a Dionisos a la meseta y al bosquecillo de chopos y se eleva Apolo hasta los túmulos del cívico grupo para sancionar súplicas y provocar esperanzas.

El profesor Roy Harvey Pearce citó:

"Estos salvajes son bárbaros tártaros e hijos de Caín". Aunque alguien informó cierta vez: "Ellos no rehúsan reconocer la verdad si se les presenta en forma verosímil". ¿Es esto posible?

\section{Henry David Thoreau,}

el más popular material erudito de lectura allende los mares para nuestras fuerzas armadas, porque mientras trabajan y esperan ven ante ellas, entre la sombra verde,

su rojiza imagen, dijo "indios" al pronunciar su última palabra cuando murió.

Leyendo hoy este manual de sabiduría,

en las ensenadas inmóviles encontramos nuestras imágenes.

Y, en emboscada junto a la propia fuente, las comprariamos. Es un acto de amor solicitar su salvación.

Una de las partes contratantes confirma el precio de la compra y nos devuelve el cambio, su redentora señal del negocio:

NOSOTROS LOS CANÍBALES DEBEMOS AYUDAR A ESTOS CRISTIANOS.

Josephine Miles, Poems, 1930-1960 